DOI https://doi.org/10.15589/znp2021.4(487).13

UDC 544.478

\title{
INNOVATIVE TECHNOLOGIES OF FLUE GAS NEUTRALIZATION IN CARBON GRAPHITE PRODUCING UNITS
}

\section{ІННОВАЦІЙНІ ТЕХНОЛОГІЇ ЗНЕШКОДЖЕННЯ ДИМОВИХ ГАЗІВ ВУГЛЕГРАФІТОВИХ ВИРОБНИЦТВ}

\author{
Olena I. Ivanenko ${ }^{1}$ \\ olenka.vasaynovich@gmail.com \\ ORCID: 0000-0001-6838-5400 \\ Mykola D. Gomelya ${ }^{1}$ \\ m.gomelya@kpi.ua \\ ORCID: 0000-0003-1165-7545 \\ Yevgen M. Panov ${ }^{1}$ \\ panov@rst.kpi.ua \\ ORCID: 0000-0002-4885-2777 \\ Ganna G. Trokhymenko ${ }^{2}$ \\ antr@ukr.net \\ ORCID: 0000-0002-0835-3551 \\ Sergii V. Plashykhin ${ }^{1}$ \\ plashihin@rambler.ru \\ ORCID: 0000-0003-0039-3302 \\ Tetyana A. Overchenko ${ }^{1}$ \\ overchenko.tanya@gmail.com \\ ORCID: 0000-0002-5883-6228 \\ Tamara V. Krysenko ${ }^{1}$ \\ tavok@ukr.net \\ ORCID: 0000-0002-9903-6884 \\ Serhii D. Dovholap ${ }^{1}$ \\ s.dovholap@gmail.com \\ ORCID: 0000-0002-2456-2249
}

\author{
О. І. Іваненко ${ }^{1}$, \\ докт. техн. наук, доцент \\ М. Д. Гомеля ${ }^{1}$, \\ докт. техн. наук, професор \\ С. М. Панов ${ }^{1}$, \\ докт. техн. наук, професор \\ Г. Г. Трохименко \\ докт. техн. наук, професор \\ С. В. Плашихін ${ }^{1}$, \\ канд. техн. наук, старший викладач
}

Т. А. Оверченко ${ }^{1}$, канд. техн. наук, старший викладач

Т. В. Крисенко ${ }^{1}$, канд. техн. наук, доцент

С. Д. Довголап ${ }^{1}$, аспірант

\section{National Technical University of Ukraine “Igor Sikorsky Kyiv Polytechnic Institute”, Kyiv Admiral Makarov National University of Shipbuilding, Mykolaiv ${ }^{2}$ \\ Національний технічний університет Украйни «Київський політехнічний інститут імені Ггоря Сікорського», м. Київ Начіональний університет кораблебудування імені адмірала Макарова, м. Миколаӥв}

\begin{abstract}
It is recommended to use extensively manganese dioxide catalyst based on a carrier of natural zeoliteclinoptilolite for purufucation of industrial flue gases from carbon monoxide and volatile resinous substances in view of its availability and environmental safety. The ecological safety of using manganese dioxide catalyst based on zeolite carrier can be justified not only by the possibility of producing the catalyst from spent sorbents for purifying manganesecontaining natural water, but also by the safety of disposal of spent catalysts. The zeolite catalyst is proposed to be placed in containers in chamber passages with a temperature of $320-390^{\circ} \mathrm{C}$ in kilns for electrode blanks, which is an innovative engineering solution to the problem of purification of flue gases from carbon monoxide.

The proposed scientific and engineering solution for using containers with a catalyst directly in the kiln chambers does not require significant capital expenditures for production re-equipment and construction of individual catalytic gas treatment plants. However, the installaition in containers and the replacement of the catalyst after its being spent will require an increase in the downtime of the carbon graphite producing plant between kiln operations. The most rational recent engineering solution consists in the use of aerated concrete blocks with catalyst, which can be quickly and conveniently placed directly on the carbon material of electrode charge in the sub-basement space of the kiln
\end{abstract}




\section{ТЕХНОЛОГІЇ ЗАХИСТУ НАВКОЛИШНЬОГО СЕРЕДОВИЩА № 4- 2021}

chambers. The advantage of using ferrite material as active substance of porous catalysts, along with high efficiency, is their inertness and stability in the environment, which does not create problems with the disposal of catalytic systems after being spent. High utilization efficiency of zeolite and block porous catalysts in oxidation of volatile resinous substances has been shown. It is established that manganese dioxide catalyst based on aerated concrete carrier has a higher oxidizing capacity as compared with manganese dioxide zeolite catalyst. The defining advantage of the use of aerated concrete block catalysts, along with the ease of installation, is their long service life after which the utilization at units of electrode industry is possible which will reduce material production costs and will conserve natural resources. Key words: porous block catalyst; zeolite catalyst; carbon monoxide; volatile resinous substances.

Анотація. Рекомендовано широке використання для очищення димових газів промислових виробництв від монооксиду вуглецю та летких смолистих речовин діоксидмарганцевого каталізатора на носії з природного цеоліту-кліноптилоліту, враховуючи його доступність та екологічну безпечність. Екологічну безпечність застосування діоксидмарганцевого каталізатора на цеолітовому носії можна аргументувати не тільки можливістю отримання каталізатора з відпрацьованих сорбентів для очищення марганцевмісної природної води, а й безпечністю захоронення відпрацьованих каталізаторів. Цеолітовий каталізатор запропоновано розміщувати в контейнерах у каналах камер із температурою $320-390^{\circ} \mathrm{C}$ печей випалювання електродних заготовок, що $\epsilon$ інноваційним технічним рішенням проблеми очистки димових газів від монооксиду вуглецю. Запропоноване науково-технічне рішення з використання контейнерів із каталізатором безпосередньо в камерах печі випалювання не вимагає значних капітальних витрат на переоснащення виробництва та будівництво окремих споруд каталітичного газоочищення. Проте облаштування контейнерів та заміна каталізатора після його відпрацювання вимагатиме підвищення терміну простою на підприємстві вуглеграфітового виробництва між кампаніями випалювання. Найбільш раціональним новітнім технічним рішенням $є$ застосування газобетонних блоків із каталізатором, які швидко та зручно можуть бути розташовані безпосередньо на вуглецевому матеріалі пересипки електродів у підсклепінному просторі камер печей випалювання. Перевагами використання феритного матеріалу як активної речовини пористих каталізаторів поряд із високою ефективністю $\epsilon$ їх інертність та стійкість у довкіллі, що не створюватиме проблем з утилізацією каталітичних систем після відпрацювання. Показано високу ефективність застосування цеолітових та блочних пористих каталізаторів під час окиснення летких смолистих речовин. Визначено, що діоксидмарганцевий каталізатор на газобетонному носії має вищу окиснювальну здатність порівняно з діоксидмарганцевим цеолітовим каталізатором. Визначальною перевагою застосування блочних газобетонних каталізаторів поряд зі зручністю встановлення є довготривалий термін їх експлуатації, після завершення якого можлива утилізація блоків на підприємствах електродної промисловості, що призведе до зниження матеріальних затрат на виробництві, а також збереження природних ресурсів.

Ключові слова: пористий блочний каталізатор; цеолітовий каталізатор; монооксид вуглецю; леткі смолисті речовини.

\section{PROBLEM FORMULATION}

The problem brought to focus in the investigation is to develop the leading-edge resource-saving high-efficiency engineering solutions for the detoxification of toxic components of flue gases in carbon graphite producing units, which will cumulatively increase the environmental safety in metallurgical, machinebuilding and chemical industries, taking into account the life cycle of carbon graphite products.

\section{ANALYSIS OF RECENT INVESTIGATIONS AND PUBLICATIONS}

The production of carbon graphite electrode products for using in metallurgical and electrochemical industries consists of a number of technological processes and operations the main of which is heat treatment of coal, during which the processes of pyrolysis and gasification of coal mass accompanied by significant gas emissions take place. Carbon monoxide and volatile resinous substances which form an increased man-made load on the atmosphere are the main harmful components of exhaust gases.
The process of cleaning gas emissions can be based on high-temperature neutralisation, adsorption, absorption and catalytic methods. In large volumes of waste gases to be cleaned, the method of high-temperature combustion requires high energy consumption, and methods based on the absorption of harmful substances from exhaust gases for the purpose of sanitary cleaning of gases require a significant amount of sorbent and, as a rule, high energy consumption for regeneration thereof [1]. It should be noted that the method of high-temperature combustion which is mainly used in enterprises for the manufacturing carbon graphite electrode products can not reduce carbon monoxide emissions up to maximum allowable value of $250 \mathrm{mg} / \mathrm{m}^{3}$. In addition, high-temperature combustion simultaneously increases the proportion of no less harmful nitrogen oxides. Catalytic method is the most effective tool for neutralization of pollutants up to the level of maximum allowable concentrations [2]. The catalytic method is universal and can be used for deep purification of various process gases [3]. At the same time harmful 
inclusions turn into less harmful and harmless ones. The main direction of development of catalytic methods is to create catalysts capable to operate at low temperatures. However, along with good performance, such catalysts are characterized by high cost and, sometimes, by limited availability [5]. Optimal performance is shown by catalysts based on oxides of transition metals [6] and ferrite materials [7]. Among the transition metal compounds for the oxidation of carbon monoxide, it is recommended to use manganese oxides [8] and mixture of mangan with copper oxide - hopcalite [9]. Investigations on the use of intermetallic compounds $\mathrm{NiAl}, \mathrm{NiAl}_{3}, \mathrm{Ni}_{2} \mathrm{Al}_{3}$ in the neutralization of $\mathrm{CO}$ in the flue gases of carbon electrode production are almost unique in this field, but producing alloys of pure metal powders and using separate equipment for catalysis involves significant economic costs [10].

As for the purification of gaseous emissions from resinous substances, and in the case of $\mathrm{CO}$ oxidation, metal and oxide catalysts based on precious and transition metals and also natural minerals, fireclay, metallurgical dump slag, intermetallics, mullitosilicon fibrous refractory material are used as catalysts $[11 ; 12]$. The advantage of using metallurgical slag as a manmade raw material is its cheapness and availability, but its low efficiency requires additional modification with expensive reagents - cobalt salts. Mullitosilicon fibrous refractory material, in contrast to previous catalysts, can be installed permanently at the outlet of the kiln baffle. However, mullite-silica material as also available bauxite have a common disadvantage - low service life of the catalyst due to coking.

Given that the enterprises producing electrode products emit into the environment about 4-5 million $\mathrm{m}^{3}$ of toxic flue gases per hour, the development of innovative engineering solutions for neuralization of carbon monoxide and volatile resinous substances which are a mixture of aromatic polycyclic hydrocarbons is extremely important [11].

\section{FOCUSING ON PREVIOUSLY UNSOLVED PARTS OF THE GENERAL PROBLEM}

Therefore, the analysis of available sources of information showed that the problem of the effect of heterogeneous catalytic systems and catalytic inclusions on the level of purification of exhaust gases from harmful inclusions in technological stages of carbon graphite and graphited products is almost not investigated. This can be accounted primarily for small number of powerful enterprises of carbon graphite and graphited products in the world as well as high competition among their owners for potential markets of the manufactured products. Therefore, the results of related investigations may be a trade secret of the relevant enterprises, and therefore not be disclosed in sources of scientific and technical information.

\section{THE INVESTIGATION OBJECTIVE}

The objective of the investigation is to experimentally study the utilization effectiveness of modified catalytic materials of different structure for the oxidation of toxic components of flue gases and to develop the leadingedge engineering solutions to improve the environmental safety of production of carbon graphite electrode products competitive in the world market.

\section{OBJECT AND SUBJECT OF INVESTIGATION}

The scientific novelty of the experimental investigation is to be the development of accessible, conveniently installed and easily dismantled heterogeneous catalytic systems based on the use of cheap effective catalytic inclusions which consist of compounds of manganese (IV), iron (II), iron (III), chromium (III) and be produced mainly from wastewater treatment waste in metallurgical and galvanic productions. In general, this approach will provide an opportunity to simultaneously solve the complex environmental problem of neutralization of spent electrolytes and pickling liquors. The prospect of using as catalysts of ferritic sludge with high efficiency consists in their low susceptibility to catalytic poisons as well as environmental inertness and stability which does not create problems with the disposal of catalytic systems after being used.

The object of investigation is to be the development of innovative technologies for the neutralization of flue gases in the production units of electrode carbon products for running of enterprises in metallurgical, machinebuilding and chemical industries. The subject of investigation is to be toxic emissions in the processes of heat treatment of carbon materials at the of carbon graphite producing enterprises.

\section{INVESTIGATION METHODS}

With the expansion of the variety of environmentally friendly materials in environmental protection technologies, the use of modified forms of zeolitesclinoptilolites is quite effective. Investigations on catalytic properties of these minerals, which can be effectively used in the purification of gas emission are quite promising.

Zeolite crushed stone fraction of $3-5-10 \mathrm{~mm}$ according to the specifications of TU U 08.1-00292540001:2014 "Rubble, sand and flour made of natural zeolite brand PCV from Sokyrnytsky deposit" has been used as a carrier for producing catalysts.

Treatment of zeolite by using film catalysts was performed according to the following method: a sample of zeolite $150 \mathrm{~g}$ was treated with salt solutions with a concentration of $0.025-1.66 \mathrm{~mol}-\mathrm{eq} / \mathrm{dm}^{3}\left(1-52 \mathrm{~g} / \mathrm{dm}^{3}\right)$ for $15 \mathrm{~min}$ to 24 hours.

To produce manganese dioxide catalyst, a sample of zeolite was saturated with a $\mathrm{MnCl}_{2}$ solution up to a capacity of $\mathrm{Mn}^{2+}$ ions, which was $7 \mathrm{mg} / \mathrm{g}$ [13].

At this stage of the modification, part of $\mathrm{Mn}^{2+}$ cations penetrates into passages of clinoptilolite (Cli) and replaces 


\section{ТЕХНОЛОГІЇ ЗАХИСТУ НАВКОЛИШНЬОГО СЕРЕДОВИЩА № 4- 2021}

the exchange cations of zeolite (preferably $\mathrm{Na}^{+}$and $\mathrm{Ca}^{2+}$ ) by the reactions:

$$
\begin{aligned}
& \mathrm{NaCli}+1 / 2 \mathrm{Mn}^{2+} \rightleftarrows \mathrm{Mn}_{1 / 2} \mathrm{Cli}+\mathrm{Na}^{+}, \\
& \mathrm{Ca}_{1 / 2} \mathrm{Cli}+1 / 2 \mathrm{Mn}^{2+} \rightleftarrows \mathrm{Mn}_{1 / 2} \mathrm{Cli}+1 / 2 \mathrm{Ca}^{2+} .
\end{aligned}
$$

The rest of $\mathrm{Mn}^{2+}$ in the form of chloride aqueous solution simply fills the macro- and mesopores of the intercrystalline space of the mineral and also indirectly replaces the outer surface exchange cations by the above reactions (1), (2).

Then, the $\mathrm{MnCl}_{2}$ solution was decanted and zeolite was treated for 24 hours in the ratio of $\left[\mathrm{Mn}^{2+}\right]:\left[\mathrm{Mn}^{6+}\right]=3: 2$ with $\mathrm{KMnO}_{4}$ solution. In this case, complex chemical transformations take place in the produced reaction system. $\mathrm{K}^{+}$cations, which are more selective to clinoptilolite, pass from permanganate solution into zeolite passages, simultaneously displacing $\mathrm{Mn}^{2+}$ ions into aqueous phase by ion exchange reaction:

$$
\mathrm{Mn}_{1 / 2} \mathrm{Cli}+\mathrm{K}^{+} \rightleftarrows \mathrm{KCli}+1 / 2 \mathrm{Mn}^{2+} .
$$

Oxidation reaction of double-charged manganese ion displaced by permanganate anion up to formation of insoluble manganese dioxide takes place at the boundary of necks of zeolite passages and aqueous solution, which can be simplified as follows:

$$
x \mathrm{Mn}^{2+}+z \mathrm{MnO}_{4}^{-} \rightarrow n \mathrm{MnO}_{2} \downarrow .
$$

It should be noted that the process of ion exchange of all manganese cations for potassium in clinoptilolite passages is not instantaneous, and accordingly the delivery of $\mathrm{Mn}^{2+}$ to oxidation zone is very stretched in time. This, on the one hand, promotes the formation of a strong crystalline precipitate of $\mathrm{MnO}_{2}$. On the other hand, the lack of reducing agent creates conditions for formation of non-stoichiometric manganese oxide compounds that have increased chemisorption capacity to interact with outer surface atoms of zeolite. The occurence of such compounds is especially important for creation of primary highly adhesive growth centers of $\mathrm{MnO}_{2}$ crystals on outer surface of clinoptilolite.

In macro- and mesopores, the reduction of doublecharged manganese cation occurs as in ordinary aqueous solutions by the reaction:

$$
3 \mathrm{MnCl}_{2}+2 \mathrm{KMnO}_{4}+2 \mathrm{H}_{2} \mathrm{O} \rightarrow 5 \mathrm{MnO}_{2} \downarrow+2 \mathrm{KCl}+4 \mathrm{HCl} \text {. }
$$

In this case, $\mathrm{MnO}_{2}$, according to the habitus oftheagglomerationsformedbyitand theshapeofthezeolite pores, can either be firmly held in the intercrystalline space of zeolite, or leave it when slight mechanical effects occur.

After modification, the zeolite sample was washed from weakly fixed on the surface modification products with distilled water and kept under normal conditions up to air-dry state. The total manganese content in the air-dry modified sample of clinoptilolite was $11.42 \mathrm{mg} / \mathrm{g}$, which in terms of $\mathrm{MnO}_{2}$ is $1.8 \%$.

To produce a copper-ferrite catalyst based on zeolite, a sample of zeolite was treated with a mixture of solutions of copper sulfate (II) and ferrous sulfate (II) with a concentration ratio of $\left[\mathrm{Cu}^{2+}\right]:\left[\mathrm{Fe}^{2+}\right]=1: 4$, soaked for 1 hour, then precipitated on surface of zeolite by using $20 \%$ ammonia solution with the formation of copper ferrite precipitate. After soaking for one day, the zeolite was filtered, washed and dried at room temperature [14].

To produce a chromium-ferrite catalyst based on zeolite, a sample of zeolite was treated with a mixture of solutions of potassium dichromate and iron sulfate (II) with a concentration ratio $\left[\mathrm{Cr}^{6+}\right]:\left[\mathrm{Fe}^{2+}\right]=1: 15$ for 1 hour, then chromium ferrite precipitate was precipitated on zeolite by $20 \%$ ammonia solution. After soaking for one day, the zeolite was filtered, washed and dried at room temperature [14].

To produce a ferrite catalyst based on zeolite, a sample of zeolite was treated with a mixture of solutions of ferrous sulfate (II) and ferric chloride (III) with a concentration ratio of $\left[\mathrm{Fe}^{2+}\right]:\left[\mathrm{Fe}^{3+}\right]=1: 2$ for 1 hour, then magnetite precipitate was precipitated on zeolite by using $20 \%$ ammonia solution. After soaking for one day, the zeolite was filtered, washed and dried at room temperature [14].

To produce a chromium catalyst based on zeolite, a portion of zeolite was treated with a solution of chromium sulfate (III) for 1 hour, after which a precipitate of chromium hydroxide (III) was precipitated on the zeolite by using $20 \%$ ammonia solution. After soaking for one day, the zeolite was filtered, washed and dried at room temperature [14].

To produce oxide copper-manganese catalysts $\left(\mathrm{CuO}: \mathrm{MnO}_{2}=3: 7 ; \mathrm{CuO}: \mathrm{MnO}_{2}=4: 6\right)$ on the basis of zeolite, samples of zeolite were treated with manganese chloride (II) for $1 \mathrm{~h}$, then manganese (IV) oxide was precipitated by adding permanganate potassium, soaked for one day. The manganese oxide-modified zeolite samples were then separated from the aqueous phase by decantation and treated with copper sulfate (II) taken in stoichiometric ratio. Then copper hydroxide (II) precipitates were precipitated by using $20 \%$ ammonia solution on zeolite. After soaking for one day, the zeolite samples were filtered, washed and dried at room temperature [14].

Testing of the technology of producing a catalyst for the oxidation of carbon monoxide on the basis of a mixture for the industrial production of aerated concrete was carried out at "Orientyr-Budelement", LLC (Brovary). A mixture of water and dry matter with a content of $460 \mathrm{~kg} / \mathrm{m}^{3}$ was prepared for the production of aerated concrete. The dry matter was composed of a ratio of ground sand with a fineness of $8 \mu \mathrm{m}$ to binders (cement:lime $=0.305: 1$ ), gypsum and aluminum paste, which was 0.6468: 0.314:0.0378:0.0014. Subsequently, the active substance of the catalyst was added in the amount of $5.92 \mathrm{wt} \%$ to finished aerated concrete mixture. Subsequent forming of porous blocks was carried out in the shop premises of the enterprise.

Particles of manganese dioxide catalyst were produced according to equation (5), after which 
the $\mathrm{MnO}_{2}$ precipitate was settled, washed with distilled water, soaked under normal conditions to an air-dry state and ground to a fineness of $20 \mu \mathrm{m}$. Particles of ferrite catalysts were produced according to equations [14], followed by settling, washing, grinding and mixing according to the proportion.

The investigation of the catalytic process of oxidation of carbon monoxide was carried out according to the method using a laboratory plant described in [15]. The container with the catalyst was inserted into a stainless steel tube of the thermal chamber so as to prevent the passage of gas mixture past the catalyst. The

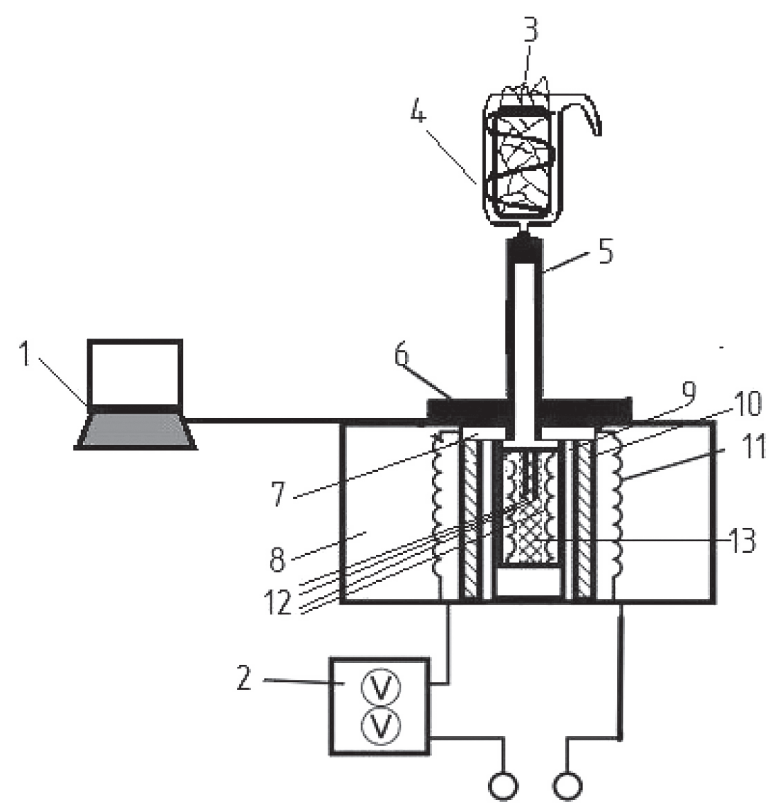

Fig. 1. Lay-out of experimental installation for investigating processes of catalytic oxidation of volatile resinous substances: 1 - digital interface of measurements; 2 - temperature regulator; 3 - ice; 4 - trap of volatile resinous substances; 5 - pipe for gas mixture discharge; 6 - metal gasket; 7 - asbestos gasket; 8 - thermal chamber; 9 - stainless steel tube; 10 - ceramic tube; 11 - heating element; 12 - thermocouples; 13 - container for moulded electrode compound and catalyst made of stainless steel mesh volumetric gas flow rate was varied in the range of 1 to $5 \mathrm{dm}^{3} / \mathrm{min}$. Catalytic purification of gas mixture from $\mathrm{CO}$ was investigated in the range of $200-400^{\circ} \mathrm{C}$. The concentration of carbon monoxide in the initial gas mixture at the inlet to the reactor was 1.1 vol. $\%$. The oxygen content in the gas mixture was maintained at the level of $20 \%$.

The degree of oxidation of carbon monoxide was calculated by the formula:

$$
\mathrm{X}_{\mathrm{CO}}=\frac{\mathrm{C}_{\mathrm{CO}}^{\text {inlet }}-\mathrm{C}_{\mathrm{CO}}^{\text {outlet }}}{\mathrm{C}_{\mathrm{CO}}^{\text {inlet }}} \cdot 100 \%,
$$

where $\mathrm{C}_{\mathrm{CO}}^{\text {inlet }}$ - volume fraction of $\mathrm{CO}$ at the inlet to the reactor, $\%$; $\mathrm{C}_{\mathrm{CO}}^{\text {outlet }}$ - volume fraction of $\mathrm{CO}$ at the reactor outlet, $\%$.

To investigate the catalytic process of oxidation of volatile resinous substances, an experimental plant was created shown in Fig. 1.

The experimental plant for catalytic oxidation of volatile resinous substances includes a sealed thermal chamber (8) consisting of a stainless steel metal tube (9) and a ceramic tube (10) with a heating element (11) in which by means of thermocouples (12) and a thermal relay (2)) set temperature is maintained by the element (11), in which a sample of extruded electrode mass and topped catalyst weighing $100 \mathrm{~g}$ in a ratio of $2: 1$ in a cylindrical container (13) was placed in a metal tube (9). Immediately before the catalytic experiment, the catalyst grain was subjected to heat treatment at a temperature of $450^{\circ} \mathrm{C}$ for 2 hours. Crushed ice mixed with salt was placed in the inner part of trap (4). Catalytic purification of gas mixture from resinous substances was investigated in the temperature range 200 to $400^{\circ} \mathrm{C}$.

Before the start of the investigations, trap (4) was thoroughly cleaned with o-Xylene, washed with water, dried in a drying oven to constant weight and measured the weight $\mathrm{m}_{\text {trap}}, \mathrm{g}$, was measured.

After finishing condensation of resinous substances, the trap was dried and the weight $\mathrm{m}_{\text {trap+resin, }} \mathrm{g}$, was measured.

Table 1. Degree of the oxidation of carbon monoxide when using oxide catalysts applied on zeolite carrier

\begin{tabular}{|c|c|c|c|c|c|c|c|}
\hline \multirow[b]{2}{*}{$\mathbf{T},{ }^{\circ} \mathbf{C}$} & \multicolumn{7}{|c|}{ Degree of the oxidation of carbon monoxide, \% } \\
\hline & 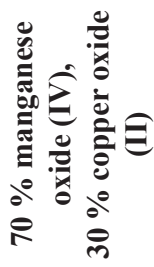 & 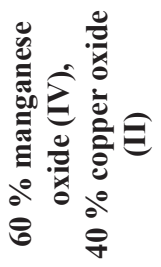 & 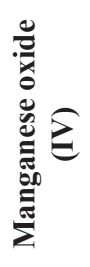 & 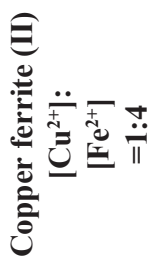 & 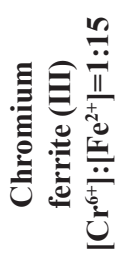 & 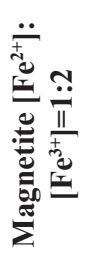 & 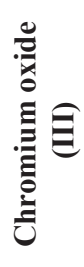 \\
\hline 250 & 63.63 & 23.63 & 37.27 & 20.9 & 47.27 & 26.36 & 27.27 \\
\hline 300 & 72.03 & 55.71 & 52.17 & 20.75 & 58.04 & 30.07 & 41.72 \\
\hline 350 & 77.27 & 75.75 & 81.76 & 24.24 & 73.48 & 43.18 & 46.97 \\
\hline 400 & 100 & 85.30 & 92.76 & 41.18 & 82.35 & 48.53 & 55.88 \\
\hline
\end{tabular}


The mass of isolated resinous substances in blank experiment without catalyst $\left(\mathrm{m}_{\text {resin. idle }}\right)$ and unoxidized resinous substances $\left(\mathrm{m}_{\text {resin. }}\right)$ was calculated by the formula:

$$
\mathrm{m}_{\text {resin. idle }} ; \mathrm{m}_{\text {resin. }}=\mathrm{m}_{\text {trap+resin. }}-\mathrm{m}_{\text {trap }}, \Gamma \text {. }
$$

The oxidation degree of volatile resinous substances was calculated by the formula:

$$
\mathrm{X}_{\text {resin. }}=\frac{\mathrm{m}_{\text {resin. idle }}-\mathrm{m}_{\text {resin. }}}{\mathrm{m}_{\text {resin. idle }}} \cdot 100 \%
$$

\section{BASIC MATERIAL}

When investigating the efficiency of purification of the gas mixture from carbon monoxide using a number of oxide catalysts applied on zeolite carrier, we can conclude that the most effective catalyst in the entire temperature range is a catalyst consisting of $70 \%$ manganese oxide (IV) and $30 \%$ copper oxide (II) (Table 1 ).

When using copper oxide-manganese catalyst composition of $\mathrm{CuO}: \mathrm{MnO}_{2}=3: 7$, even at the temperature of $250^{\circ} \mathrm{C}$, the highest degree of oxidation of carbon monoxide among the proposed active substances on a zeolite carrier is achieved, which is $63.63 \%$.

The highest catalytic activity is shown by the specified catalyst at a temperature of $300^{\circ} \mathrm{C}$, while the oxidation degree is $72.03 \%$. At $350^{\circ} \mathrm{C}$, the copper-manganese oxide catalyst somewhat loses its activity. At this temperature, the most effective is manganese oxide (IV), the degree of oxidation of carbon monoxide under these conditions is $81.76 \%$. At the temperature of $400^{\circ} \mathrm{C}$ when using coppermanganese oxide catalyst $100 \%$ oxidation of carbon monoxide is achieved.

The next in catalytic activity is to be manganese oxide (IV), the efficiency whereof is comparable with the use of copper-manganese oxide catalyst. Although the degree of oxidation when using manganese oxide (IV) is slightly lower, it is still more environmentally friendly, as it does not contain a heavy metal, i. e. copper. Oxide coppermanganese catalyst composition of $\mathrm{CuO}: \mathrm{MnO}_{2}=4: 6$ and chromium ferrite (III) are even less effective, but acceptable in the technology of gas purification of waste gases of carbon graphite producing enterprises. The degree of oxidation when used at a temperature of $400^{\circ} \mathrm{C}$ is $85.30 \%$ and $82.35 \%$, respectively. Chromium oxide (III), magnetite and copper ferrite (II) have low catalytic activity, the feasibility of their use in environmental technologies is the lowest.

Therefore, the environmental safety of the use of manganese dioxide catalyst based on zeolite can be justified not only by the possibility of producing a catalyst from spent sorbents for purification of manganese-containing natural water, but also by the safety of disposal of spent catalysts.

It is known that in multi-chamber kilns for electrode blanks, the maximum increase in the concentration of carbon monoxide in flue gases occurs at temperatures of $320-390^{\circ} \mathrm{C}[11]$. Therefore, the placement of containers with catalyst in passages of chambers with a appropriate temperature can be an innovative technical solution as to the problem of purification of flue gases of kilns for electrode blanks from carbon monoxide (Fig. 2).

The developed scientific and technical solution for using containers with a catalyst directly in kiln chambers does not require significant capital expenditures for re-equipment of production process and construction of individual catalytic gas treatment plants. However, arrangement of the containers and replacement of spent catalyst will require an increase in the downtime of the carbon graphite producing plant between kilning campaigns.

The most efficient design solution consists in the use of aerated concrete blocks with catalyst, which can be quickly and conveniently placed directly on carbon material of electrodes in the sub-basement space of kiln chambers.

Based on the results of oxidative catalytic activity against carbon monoxide (Table 1), it is justified to use oxide copper-manganese catalysts $\left(\mathrm{CuO}: \mathrm{MnO}_{2}=3: 7 ; 4: 6\right)$, manganese oxide (IV), chromium ferrite (III) as active substance catalysts to be included in aerated concrete carrier. Given the advantages of using magnetite as a ferrite sludge in environmental protection technologies, it is advisable to use it in various combinations with highly efficient catalysts.

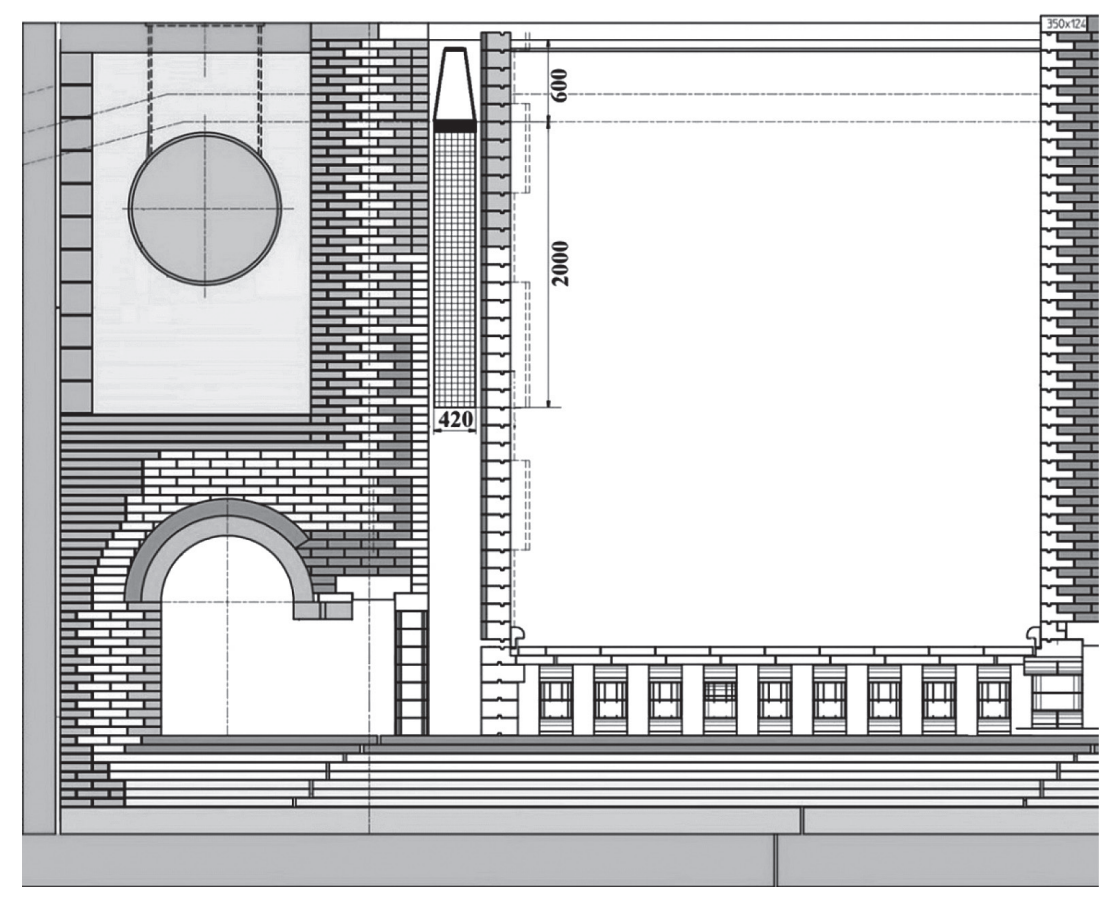

Fig. 2. Placement of the container with catalytic material on zeolite carrier in firing kiln 
As the investigations have shown that when using oxide copper-manganese catalysts included in the aerated concrete carrier, along with the case of application on zeolite, the maximum degree of oxidation of carbon monoxide at the temperature of $400^{\circ} \mathrm{C}$ (Table 2) is achieved. However, the inclusion of ferritic materials in a mixture with manganese oxide (IV) in porous concrete matrix at lower temperatures of $250-350^{\circ} \mathrm{C}$ provides better catalytic purification. Nevertheless, only the use of manganese oxide (IV) provides the highest purification efficiency among all the investigated catalysts, which is $76 \%$ at the temperature of $250^{\circ} \mathrm{C}$. The characteristic feature of using ferritic catalytic materials on a porous carrier consists in better catalytic activity of magnetite than one of chromium ferrite (III) in contrast to the activity of these catalysts based on zeolite carrier, which can be attributed to a more ordered structure of produced magnetite as compared with chromium ferrite (III), and, for sure, the number of active centers per weight unit of block catalyst. The combined use of magnetite and chromium ferrite (III) provides the degree of oxidation of carbon

Table 2. Degree of the oxidation of carbon monoxide when using oxide catalysts included in aerated concrete matrix

\begin{tabular}{|c|c|c|c|c|}
\hline \multirow{2}{*}{ T, ${ }^{\circ} \mathrm{C}$} & \multicolumn{3}{|c|}{$\begin{array}{c}\text { Degree of the oxidation of carbon } \\
\text { monoxide, \% }\end{array}$} \\
\cline { 2 - 5 } & $\mathbf{2 5 0}$ & $\mathbf{3 0 0}$ & $\mathbf{3 5 0}$ & $\mathbf{4 0 0}$ \\
\hline $\begin{array}{c}70 \% \text { manganese } \\
\text { oxide (IV), } \\
30 \% \text { copper oxide (II) }\end{array}$ & 48.00 & 58.04 & 62.12 & 100 \\
\hline $\begin{array}{c}60 \% \text { manganese } \\
\text { oxide (IV), } \\
40 \% \text { copper oxide (II) }\end{array}$ & 60.00 & 76.69 & 84.85 & 100 \\
\hline $\begin{array}{c}\text { manganese oxide (IV) } \\
\text { chromium ferrite (III) } \\
{\left[\mathrm{Cr}^{6+}\right]:\left[\mathrm{Fe}^{2+}\right]=1: 15}\end{array}$ & 76.00 & 76.69 & 81.06 & 92.87 \\
\hline $\begin{array}{c}\text { magnetite } \\
{\left[\mathrm{Fe}^{2+}\right]:\left[\mathrm{Fe}^{3+}\right]=1: 2}\end{array}$ & 16.00 & 53.38 & 61.36 & 70.59 \\
\hline $\begin{array}{c}50 \% \text { manganese } \\
\text { oxide (IV), } \\
50 \% \text { chromium ferrite } \\
(\mathrm{III})\left[\mathrm{Cr}^{6+}\right]:\left[\mathrm{Fe}^{2+}\right]=1: 15\end{array}$ & 80.00 & 88.35 & 92.42 & 100 \\
\hline $\begin{array}{c}50 \% \text { manganese } \\
\text { oxide (IV), }\end{array}$ & 48.00 & 60.37 & 77.27 & 100 \\
$\begin{array}{c}50 \% \text { magnetite } \\
{\left[\mathrm{Fe}^{2+}\right]:\left[\mathrm{Fe}^{3+}\right]=1: 2}\end{array}$ & & & & \\
\hline $\begin{array}{c}50 \% \text { chromium } \\
\text { ferrite (III) } \\
{\left[\mathrm{Cr}^{6+}\right]:\left[\mathrm{Fe}^{2+}\right]=1: 15,} \\
50 \% \text { magnetite } \\
{\left[\mathrm{Fe}^{2+}\right]:\left[\mathrm{Fe}^{3+}\right]=1: 2}\end{array}$ & 20.00 & 25.41 & 39.39 & 85.29 \\
\hline $\begin{array}{c}50 \% \text { manganese } \\
\text { oxide (IV), } \\
25 \% \text { chromium } \\
\text { ferrite (III) } \\
{\left[\mathrm{Cr}^{6+}\right]:\left[\mathrm{Fe}^{2+}\right]=1: 15,} \\
25 \% \text { magnetite } \\
{\left[\mathrm{Fe}^{2+}\right]:\left[\mathrm{Fe}^{3+}\right]=1: 2}\end{array}$ & 26.00 & 37.06 & 46.97 & 70.59 \\
\hline
\end{tabular}

monoxide at the level of $85.29 \%$ only at the temperature of $400^{\circ} \mathrm{C}$, which completely allows using the specified mixture as an active substance of catalyst in the forming process for porous blocks with the subsequent use in kiln chambers at the specified temperature.

As it is already mentioned, fabricated aerated concrete blocks with a catalyst are proposed to be placed on the surface of pouring material in kilns for electrode products, which is the latest engineering solution to the problem of highly efficient flue gas purification from carbon monoxide.

The design concept of manufacturing the aerated concrete blocks includes forming holes therein to increase the specific contact surface of catalyst and carbon monoxide flue gases in carbon graphite producing units (Fig. 3, 4).

The environmental safety of using porous catalysts is confirmed by the possibility of utilizating spent blocks for the production of engineering structures in electrode industry as secondary crushed stone filling for concrete which, in general, will reduce material production costs and will conserve natural resources.

The simultaneous ability of metal catalysts to oxidize volatile resinous substances released mainly apart from the shop for moulding electrodes and pitch storage facilities in the process of firing electrodes is quite indicative in the investigation of oxidizing properties of metal catalysts based on zeolite and aerated concrete in relation to carbon monoxide [16], being quite toxic substances that contain benzopyrene in the amount of $0.8-2 \%$ [17]. If we take into account that, on average, the electrode producing unit emits $60-80 \mathrm{~kg}$ of benzopyrene per day, it becomes vital using effective catalysts to neutralize resinous substances. The investigations have shown that manganese dioxide catalyst based on aerated concrete carrier has a slightly higher oxidizing ability in relation to volatile resinous substances as compared with manganese dioxide zeolite catalyst (Table 3). It can be motivated by the fact that the number of available active catalytic centers in catalyst based on aerated concrete is higher due to the higher content of manganese oxide (IV) in its structure. If we take into account that the total manganese content in terms of $\mathrm{MnO}_{2}$ in dry matter of air-dry sample of zeolite-clinoptilolite is $18 \mathrm{~g} / \mathrm{kg}$, at the same time, in the production of aerated concrete blocks the amount of manganese oxide (IV) is $27 \mathrm{~g} / \mathrm{kg}$ when taking into account physicochemical parameters of aerated concrete, given swelling of the poured aerated concrete mass at $2 / 3$ or $3 / 4$ of the form height. Separately, it should be noted that a correlation between the results of investigations on the oxidation of carbon monoxide and resinous substances using block porous catalysts was observed. When heated at the same rate and over the same temperature range, the same highest oxidation efficiency at $400^{\circ} \mathrm{C}$ was observed for a mixture of chromium ferrite and manganese dioxide in a ratio of $1: 1$, copper-manganese oxide catalyst $\left(\mathrm{CuO}: \mathrm{MnO}_{2}=4: 6\right)$, and manganese oxide (IV), which are $96.23 \%, 92.14 \%$ and $91.19 \%$, respectively. 

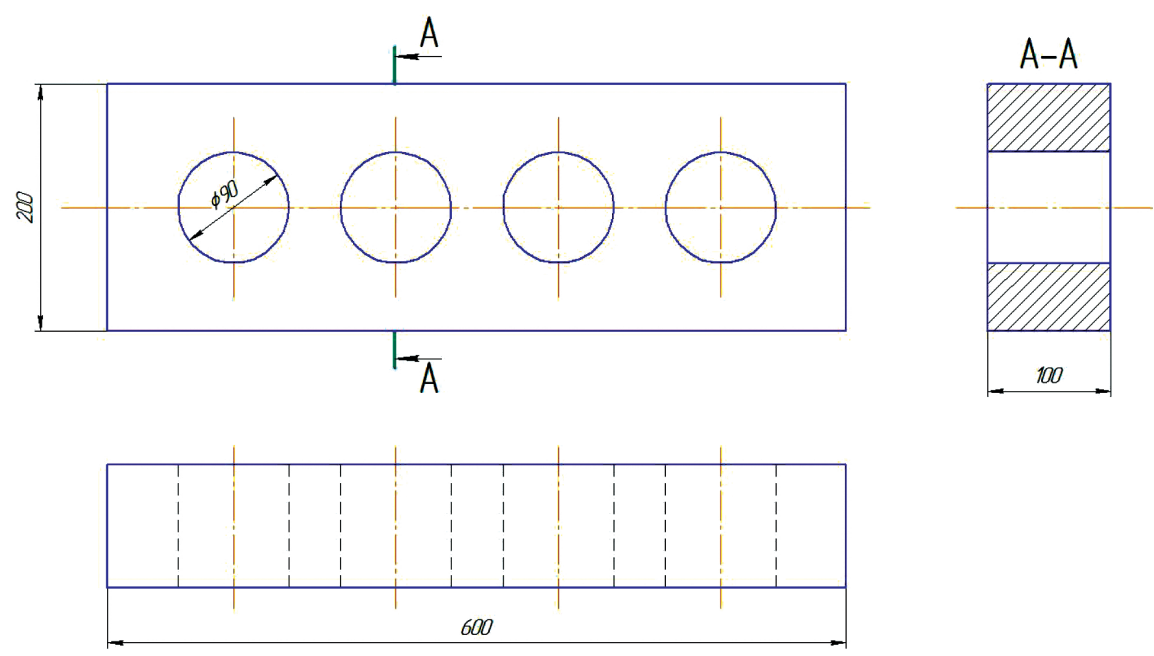

Fig. 3. Drawing of the aerated concrete block with 4 holes
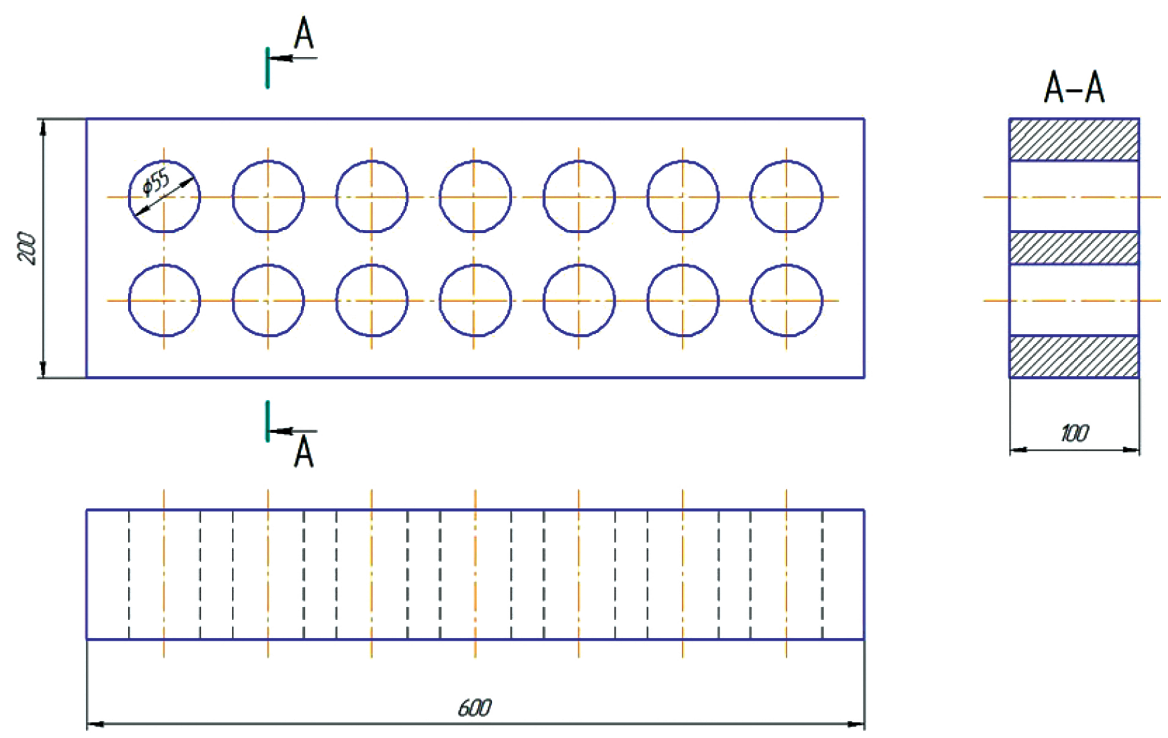

Fig. 4. Drawing of the aerated concrete block with 14 circular holes

Table 3. Degree of oxidation of volatile resinous substances when using oxide catalysts on zeolite and aerated concrete carrier

\begin{tabular}{|c|c|c|c|c|}
\hline Catalyst & $\mathbf{m}_{\text {trap }}, \mathbf{g}$ & $\mathbf{m}_{\text {trap+resin. }}, \mathbf{g}$ & $\mathbf{m}_{\text {resin. idle, }}, \mathbf{m}_{\text {resin. }}, \mathbf{g}$ & $\mathbf{X}_{\text {resin. }} \%$ \\
\hline without catalyst & 290.22 & 293.40 & 3.18 & - \\
\hline manganese oxide (IV) on zeolite carrier & 290.22 & 290.55 & 0.33 & 89.62 \\
\hline \multicolumn{5}{|c|}{ on aerated concrete carrier } \\
\hline manganese oxide (IV) & 290.22 & 290.50 & 0.28 & 91.19 \\
\hline chromium ferrite (III) & 290.22 & 291.00 & 0.78 & 75.47 \\
\hline magnetite & 290.22 & 290.70 & 0.48 & 84.91 \\
\hline $50 \%$ manganese oxide (IV), $50 \%$ magnetite & 290.22 & 290.53 & 0.31 & 90.25 \\
\hline $60 \%$ manganese oxide (IV), $40 \%$ copper oxide i (II) & 290.22 & 290.47 & 0.25 & 92.14 \\
\hline $70 \%$ manganese oxide (IV), $30 \%$ copper oxide (II) & 290.22 & 290.51 & 0.29 & 90.88 \\
\hline $50 \%$ manganese oxide (IV), $50 \%$ chromium ferrite (III) & 290.22 & 290.34 & 0.12 & 96.23 \\
\hline $50 \%$ chromium ferrite (III), $50 \%$ magnetite & 290.22 & 291.11 & 0.89 & 72.01 \\
\hline $\begin{array}{l}50 \% \text { manganese oxide (IV), } 25 \% \text { chromium ferrite (III), } \\
25 \% \text { magnetite }\end{array}$ & 290.22 & 291.15 & 0.93 & 70.75 \\
\hline
\end{tabular}


When using magnetite as well as a mixture of magnetite and manganese oxide (IV), high results were achieved on the oxidation of resinous substances which fully confirms the possibility of using ferrite material for manufacturing catalysts for neutralization of toxic emissions of electrode producing plants.

Subsequent investigations will show the possibility of producing catalytic ferrite materials using directly the system of treatment of metal-containing wastewater of machinebuilding companies by means of ferrite method.

\section{CONCLUSIONS}

Given low cost, availability and high performance, the zeolite catalyst can be successfully used for the oxidation of carbon monoxide and volatile resinous substances of flue gases of carbon graphite producing units, while providing a fundamentally waste-free environmentally friendly technology. In addition, natural zeolite-clinoptilolite is a fairly common mineral, which exists mainly in the form of sedimentary rocks of volcanic origin. Such geological deposits are of great commercial interest because these zeolite tuffs are often quite clean and can be extracted using simple technologies.

As compared with the arrangement of zeolite catalyst container in kiln chambers, the placement of block industrial catalysts directly on the surface of chamber filling will not only ensure maximum contact between the reactants, but also greatly simplify the formation of working space in real conditions of carbon monoxide neutralization. Also, the advantage of using block porous catalysts along with the ease of installation consists in their long service life which is associated with a low degree of adhesion of resinous substances during operation. In addition, at the end of the kilning campaign, it is possible to use spent blocks for manufacture of engineering structures in electrode prodicing industry, which will reduce material production costs in, as well as will preserve of natural resources.

\section{REFERENCES}

[1] Feyzbar-Khalkhali-Nejad, F., Hassani, E., Rashti, A., Oh, T.-S. (2021). Adsorption-based CO removal: Principles and materials. Journal of Environmental Chemical Engineering, no. 9(4), 105317.

[2] Duan, D., Wang, H., Shi, W., Sun, Z. (2018). Nanoporous Oxides and Nanoporous Composites. Intechopen. URL: $10.5772 /$ intechopen. 82028

[3] Freund, H.-J., Meijer, G., Scheffler, M., Schlçgl, R., Wolf, M. (2011). CO oxidation as a prototypical reaction for heterogeneous processes. Berlin: Germany. Angew. Chem. Int. Ed. no. 50, pp. 10064-10094.

[4] Patel, D. M., Kodgire, P., Dwivedi, A. H. (2019). Low temperature oxidation of carbon monoxide for heat recuperation: A green approach for energy production and a catalytic review. Journal of Cleaner Production, $97 \mathrm{p}$.

[5] Metal Oxides. Chemistry and Applications. Chemical Industries. (2019). Berkeley, California: CRC Press. 808 p.

[6] Royer, S., Duprez, D. (2011). Catalytic Oxidation of Carbon Monoxide over Transition Metal Oxides. ChemCatChem, no. 3(1), pp. 24-65.

[7] Lou, J.C., Chang, C.K. (2006). Catalytic oxidation of CO over a catalyst produced in the ferrite process. Environmental Engineering Science, no. 23(6). pp. 1024-1032.

[8] Iablokov, V. (2011). Manganese and Cobalt oxides as highly active catalysts for CO oxidation. Dissertation presented to obtain a $\mathrm{PhD}$ degree in Science.

[9] Biemelt, T., Wegner, K., Teichert, J., Lohe, M. R., Martin, J., Grothe, J., Kaskel, S. (2016). Hopcalite nanoparticle catalysts with high water vapour stability for catalytic oxidation of carbon monoxide. Applied Catalysis B: Environmental, no. 184, pp. 208-215.

[10] Belokon, K. V., Belokon, Y.A., Kozhemyakin, G. B., Matukhno, E. V. (2016). Environmental assessment of the intermetallic catalysts utilization efficiency for deactivation of the pollutants emitted by electrode production enterprises. Naukovyi Visnyk Natsionalnoho Hirnychoho Universytetu, no. 3. pp. 87-94.

[11] Ivanenko, O., Gomelia, N., Panov, Ye., Vahin, A., Leleka, S. (2020). Pidvyshchennya ekolohichnoyi bezpeky PrAT "Ukrayins'kyy hrafit" shlyakhom znyzhennya vykydiv monooksydu vuhletsyu. [Improving the environmental safety of PJSC "Ukrainian Graphite" by reducing carbon monoxide emissions]. Kyiv: Condor Publishing House. 138 p. [in Ukrainian]

[12] Pavlovich, L. B., Titova, O. O. (2015). Ekologicheskiye problemy metallurgicheskogo proizvodstva [Environmental problems of metallurgical production]. Novokuznetsk: Publishing Center of SibGIU. 2111 p. [in Russian]

[13] Tarasevich, Yu.I., Kulishenko, A.E., Ostapenko, R.V., Kravchenko, T.B. (2013). Issledovaniye protsessa demanganatsii vody $\mathrm{v}$ pilotnykh usloviyakh. [Investigation of the process of demanganation of water in pilot conditions]. Ukrainian chemical journal, no. 79(10). pp. 101-106. [in Russian]

[14] Radovenchik V. M., Ivanenko O. I., Radovenchik Y. V., Krisenko T. V. (2020). Zastosuvannya ferytnykh materialiv $\mathrm{v}$ protsesakh ochyshchennya vody. [Application of ferrite materials in water purification processes]. Monograph: O. V. Pshonkivskyi. 215 p. [in Ukrainian]

[15] Panov, Ye., Gomelia, N., Ivanenko, O., Vahin, A., Leleka, S. (2019). Estimation of the effect of temperature, the concentration of oxygen and catalysts on the oxidation of the thermoanthracite carbon material. Eastern-European Journal of Enterprise Technologies, no. 2/6 (98). pp. 43-50.

[16] Rosly, O. F., Efremov, V. N., Fedoruk, A. A., Slyshkina, T. V., Roslaya, N. A. (2015). Otsenka professional'nogo riska narusheniy zdorov'ya rabotnikov proizvodstva elektrodnoy produktsii. [Assessment of the occupational risk of health problems for workers in the production of electrode products]. Occupational medicine and human ecology, no. 3. pp. 167-174. [in Russian] 


\section{ТЕХНОЛОГІЇ ЗАХИСТУ НАВКОЛИШНЬОГО СЕРЕДОВИЩА № 4- 2021}

[17] Belokon, K.V. (2015). Povysheniye ekologicheskoy bezopasnosti predpriyatiy elektrodnogo proizvodstva putem kataliticheskogo obezvrezhivaniya gazovykh vybrosov. [Improving the environmental safety of electrode production enterprises by catalytic neutralization of gas emissions]. HNADU Bulletin, no. 70. pp. 42-49. [in Russian].

\section{BIBLIOGRAPHY}

[1] Feyzbar-Khalkhali-Nejad, F., Hassani, E., Rashti, A., Oh, T.-S. (2021). Adsorption-based CO removal: Principles and materials. Journal of Environmental Chemical Engineering. Vol. 9. Issue 4. 105317.

[2] Duan, D., Wang, H., Shi, W., Sun, Z. (2018). Nanoporous Oxides and Nanoporous Composites. Intechopen. URL: 10.5772/ intechopen. 82028

[3] Freund, H.-J., Meijer, G., Scheffler, M., Schlçgl, R., Wolf, M. (2011). CO oxidation as a prototypical reaction for heterogeneous processes. Berlin: Germany. Angew. Chem. Int. Ed. № 50. P. 10064-10094.

[4] Patel, D.M., Kodgire, P., Dwivedi, A.H. (2019). Low temperature oxidation of carbon monoxide for heat recuperation: A green approach for energy production and a catalytic review. Journal of Cleaner Production. 97 p.

[5] Metal Oxides. Chemistry and Applications. Chemical Industries. (2019). Berkeley, California: CRC Press. 808 p.

[6] Royer, S., Duprez, D. (2011). Catalytic Oxidation of Carbon Monoxide over Transition Metal Oxides. ChemCatChem. Vol. 3. Issue 1. P. 24-65.

[7] Lou, J.C., Chang, C.K. (2006). Catalytic oxidation of CO over a catalyst produced in the ferrite process. Environmental Engineering Science. № 23(6). P. 1024-1032.

[8] Iablokov, V. (2011). Manganese and Cobalt oxides as highly active catalysts for CO oxidation. Dissertation presented to obtain a PhD degree in Science. Universite Libre De Bruxelles, Faculte Des Sciences, Chimie Physique Des Matériaux (Catalyse - Tribologie).

[9] Biemelt, T., Wegner, K., Teichert, J., Lohe, M.R., Martin, J., Grothe, J., Kaskel, S. (2016). Hopcalite nanoparticle catalysts with high water vapour stability for catalytic oxidation of carbon monoxide. Applied Catalysis B: Environmental. № 184. P. 208-215.

[10] Belokon, K.V., Belokon, Y.A., Kozhemyakin, G. B., Matukhno, E. V. (2016). Environmental assessment of the intermetallic catalysts utilization efficiency for deactivation of the pollutants emitted by electrode production enterprises. Naukovyi Visnyk Natsionalnoho Hirnychoho Universytetu. № 3. P. 87-94.

[11] ваненко О.І., Гомеля М.Д., Панов С.М., Вагін А.В., Лелека С.В. Підвищення екологічної безпеки ПрАТ «Український графіт» шляхом зниження викидів монооксиду вуглецю. Київ : Видавничий дім «Кондор». 2020. 138 с.

[12] Павлович Л.Б., Титова О.О. Экологические проблемы металлургического производства. Новокузнецк : Издательский центр СибГИУ. 2015. 2111 с.

[13] Тарасевич Ю.И., Кулишенко А.Е., Остапенко Р.В., Кравченко Т.Б. Исследование процесса деманганации воды в пилотных условиях. Украинский химический журнал. Том 79. № 10. 2013. С. 101-106.

[14] Радовенчик В.М., Іваненко О.І., Радовенчик Я.В., Крисенко Т.В. Застосування феритних матеріалів в процесах очищення води. Біла Церква : Видавництво О.В. Пшонківський. 2020. 215 с.

[15] Panov, Ye., Gomelia, N., Ivanenko, O., Vahin, A., Leleka, S. (2019). Estimation of the effect of temperature, the concentration of oxygen and catalysts on the oxidation of the thermoanthracite carbon material. Eastern-European Journal of Enterprise Technologies. № 2/6 (98). P. 43-50.

[16] Рослый О.Ф., Ефремов В.Н., Федорук А.А., Слышкина Т.В., Рослая Н.А. Оценка профессионального риска нарушений здоровья работников производства электродной продукции. Медииина труда и экология человека. № 3. 2015. C. $167-174$.

[17] Белоконь К.В. Повышение экологической безопасности предприятий электродного производства путем каталитического обезвреживания газовых выбросов. Вестник ХНАДУ. Вып. 70. 2015. С. 42-49.

(С) Іваненко О. І., Гомеля М. Д., Панов С. М., Трохименко Г. Г., Плашихін С. В., Оверченко Т. А., Крисенко Т. В., Довголап С. Д. Дата надходження статті до редакції: 30.11.2021 Дата затвердження статті до друку: 15.12.2021 